Original Article

\title{
Regeneration and histological study of somatic embryogenesis of sugarcane (Saccharum officinarum L.) cultivar PS 864
}

\author{
Fitri Damayanti ${ }^{1,2}$, Suharsono $^{3}$, Aris Tjahjoleksono $^{3}$, Ika Mariska $^{4}$ \\ ${ }^{1}$ Department of Biology, University of Indraprasta, Jakarta, Indonesia \\ ${ }^{2}$ Plant Biology Graduate Program, Department of Biology, Bogor Agricultural University, Bogor, Indonesia \\ ${ }^{3}$ Department of Biology, Bogor Agricultural University, Bogor, Indonesia \\ ${ }^{4}$ Indonesian Center for Estate Crops Research and Development (ICECRD), Bogor, Indonesia
}

\begin{abstract}
The process affecting somatic embryo formation in sugarcane is very specific for each genotype, so the determination of the best somatic embryo regeneration medium in sugarcane clones is necessary. The objective of this study was to determine the concentration of Benzine Amino Purine (BAP) and Kinetin for somatic embryo maturation and to observe the maturation stage for somatic embryo of sugarcane cultivar PS 864 . Maturation of the nodular callus was conducted by addition of Kinetin $(0,1,3$, and $5 \mathrm{mg} / \mathrm{L})$ and BAP (0 and $5 \mathrm{mg} / \mathrm{L})$ in solid and liquid medium. The medium was optimized using glutamine. The medium for somatic embryo germination used full and half strength Murashige and Skoog medium (MS) supplemented with $20 \mathrm{~g} / \mathrm{L}$ sucrose and amino acid or growth regulator (BAP and NAA). Nodular callus well grew in solid medium, whereas callus become browning and not existence of somatic embryo maturation in liquid medium. The highest number of globular embryos (38 embryos) was produced from MS medium supplemented with 1 or $3 \mathrm{mg} / \mathrm{L}$ Kinetin combined with $5 \mathrm{mg} / \mathrm{L}$ BAP. The highest number of scutellum (21 embryos) and coleoptile (19 embryos) resulted from $3 \mathrm{mg} / \mathrm{L}$ Kinetin. The MS medium with full strength was added with $100 \mathrm{mg} / \mathrm{L} \mathrm{glutamine}$ that was the best germination medium. This medium resulted the highest percentage of somatic embryo (73.29\%) forming bipolar structure, and the largest number of leaves (4.58). Histological analysis showed that somatic embryos of sugarcane emerged from many cells through the budding process and also initiated from one cell.
\end{abstract}

Keywords: Coleoptile, embryogenic callus, globular, scutellum.

Received: 07 August 2018 Revised: 08 November 2018 Accepted: 18 November 2018

\section{Introduction}

The main technique for increasing the genetic potential of plants is breeding techniques that are key in addressing the problem of sugarcane production nationally. Sugarcane has a varying number of basic chromosomes where the variation of sugarcane chromosomes not only occur between individuals but also occurs in one individual on different cells. Sugarcane has a complexity of chromosome numbers which is one of the obstacles in genetic improvement through conventionalbased hybridization.

Propagation through in vitro techniques for plantation crops has several advantages including the improvement of genetic quality, physiology, and high purity. Sugarcane cultivation requires free procurement of pest and diseases that are essential to avoid clonal degradation caused by recurrent vegetative systems which can be obtained through tissue culture techniques. Another advantage of tissue culture can be selected as plant properties desired.

Micropropagation techniques can be reached through the path of organogenesis and somatic embryogenesis. Somatic embryogenesis pathways should be potential to be applied, because the produced seeds can be derived from a single somatic cell and can be applied to the

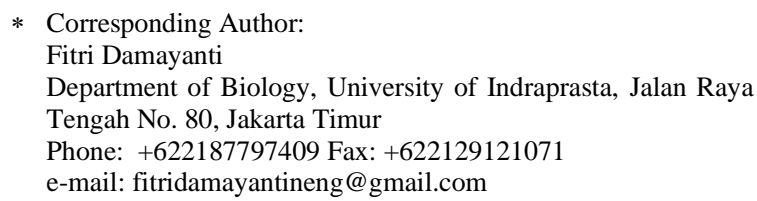

http://dx.doi.org/10.23869/bphjbr.24.1.20188

Published by () PBI East Java. Open Access www.berkalahayati.org formation of synthetic seeds (Chengalrayan et al., 2005; Pennycooke \& Towill, 2011).

Somatic embryogenesis is the process of embryo formation derived from somatic cells (haploid or diploid cells) through in vitro cultures. The developmental stage of somatic embryo in monocot plant began from the formation of globular, scutellum, and coleoptile. The important mechanism during the process of somatic embryogenesis is the division of asymmetric cells ( $\mathrm{Naz}$ et al., 2008). The success of the somatic embryogenesis process is determined by plant genotypes used as early explants (Gandonou et al., 2005), appropriate culture medium compositions, and culturally appropriate environments (Desai et al., 2004; Gill et al., 2004; Haq \& Memon 2012; $\mathrm{Naz}$ et al., 2008). The method of sugar regeneration through somatic embryogenesis has been conducted in several studies, but the method to induce somatic embryogenesis obtained was not appropriated to be applied for different varieties, so it is necessary to find somatic embryogenesis method that effective and efficient. The development stage of somatic embryo from sugarcane which has been described in detail is not yet available until now. An Understanding of embryogenesis is important for obtaining a morphogenic system by observing the cellular processes underlying the differentiation process.

The objective of this study was to develop a method of sugarcane regeneration through embryogenesis using a combination of Kinetin and BAP on MS medium (Murashige \& Skoog, 1962) and to observe the stages of formation and development of somatic embryo of 
sugarcane which was conducted, to prove the regeneration of sugarcane PS 864 histologically through somatic embryogenesis. This research provides benefits in the provision of seed regeneration techniques (prospective new varieties) in sugarcane through somatic embryogenesis induction technique that effective and efficient. Several important stages of somatic embryogenesis are expected to be recorded or visualized from the process of single cell differentiation to the formation of planlet. That expected to facilitate using and understanding of somatic embryo processes as well as in the preparation of research strategies related to the process.

\section{Method}

The research has been carried out in the Tissue Culture Laboratory of Indonesian Center for Agricultural Biotechnology \& Genetic Resources (ICABIOGRAD), Bogor and Indonesia Center for Estate Crops Research and Development (ICECRD), Bogor. The plant material used in this study was nodular callus of PS 864 sugarcane. Nodular callus was induced on MS medium containing 3 $\mathrm{mg} / \mathrm{L}$ 2,4-D, $100 \mathrm{mg} / \mathrm{L}$ glutamine, and $500 \mathrm{mg} / \mathrm{L}$ casein hydrolysate.

\section{Maturation of Somatic Embryo}

The growth regulator substances were used for somatic embryo maturation that were Kinetin $(0,1,3$, and $5 \mathrm{mg} / \mathrm{L})$ and BAP (0 and $5 \mathrm{mg} / \mathrm{L})$. The germination medium also contained $100 \mathrm{mg} / \mathrm{L}$ glutamine. The $\mathrm{pH}$ of the medium was measured 5.8 using $0.1 \mathrm{~N} \mathrm{NaOH}$ or 0.1 $\mathrm{N} \mathrm{HCl}$. The medium was compacted with the addition of $2.5 \mathrm{~g} / \mathrm{L}$ phytagel for the solid medium while the liquid medium without the addition of phytagel. The medium was sterilized using an autoclave for 20 minutes at 121 ${ }^{\circ} \mathrm{C}$. The explants were incubated in light intensity of 1200 lux at $25 \pm 20{ }^{\circ} \mathrm{C}$. The observed variables were percentage of live nodular callus, number of globular structure, scutellum, and coleoptile embryo.

The design of the study was arranged factorially in a Completely Randomized Design environment. The first factor was the growth regulator of Kinetin $(0,1,3$, and 5 $\mathrm{mg} / \mathrm{L}$ ) combined with BAP (0 and $5 \mathrm{mg} / \mathrm{L})$. The second factor was medium consistency that was MS medium (Murashige \& Skoog, 1962) in solid and liquid medium. Each treatment consisted of 10 replicates (each containing three nodular callus). Results were analyzed using STAR Nebula, Statistical Tool for Agricultural Research (IRRI, 2013 Plant Breeding Genetics and Biotechnology Biometrics and Breeding Informatics). The means were compared by using Duncan's multiple range test at $1 \%$ level of significant $(P<0.01)$. The results data were shown as mean \pm Standard Error $(\mathrm{SE})$.

\section{Germination of Somatic Embryo}

Maturation of somatic embryos in coleoptile phase were sub cultured on the germination medium. The medium for somatic embryo germination were full and half strength MS medium supplemented with $20 \mathrm{~g} / \mathrm{L}$ sucrose. In addition, germination medium also supplemented with glutamine and growth regulators (BAP and NAA). There were six kinds of germination medium, namely: 1) 1/2MS + $20 \mathrm{~g} / \mathrm{L}$ sucrose, 2) $\mathrm{MS}+20$ $\mathrm{g} / \mathrm{L}$ sucrose, 3) $1 / 2 \mathrm{MS}+20 \mathrm{~g} / \mathrm{L}$ sucrose $+100 \mathrm{mg} / \mathrm{L}$ glutamine, 4) $\mathrm{MS}+20 \mathrm{~g} / \mathrm{L}$ sucrose $+100 \mathrm{mg} / \mathrm{L}$ glutamine, 5) $1 / 2 \mathrm{MS}+20 \mathrm{~g} / \mathrm{L}$ sucrose $+100 \mathrm{mg} / \mathrm{L}$ glutamine $+0.3 \mathrm{mg} / \mathrm{L} \mathrm{BAP}+0.5 \mathrm{mg} / \mathrm{L} \mathrm{NAA}$, and 6) $\mathrm{MS}$ $+20 \mathrm{~g} / \mathrm{L}$ sucrose $+100 \mathrm{mg} / \mathrm{L}$ glutamine $+0.3 \mathrm{mg} / \mathrm{L}$ BAP $+0.5 \mathrm{mg} / \mathrm{L}$ NAA. The coleoptile structure cultured in a germination medium was incubated in light intensity of 1200 lux at $25 \pm 20{ }^{\circ} \mathrm{C}$. The observed variables were the percentage of bipolar structure, root length, and number of leaves.

\section{Histology and Microscopic Observation}

Microscopic observations were performed to observe the somatic embryo maturation stage. This observation was performed on the embryogenic cell population using a stereo microscope with a magnification of 40x. Data on the number of globular, scutellum and coleoptile embryo were the average values obtained from each treatment of the maturation medium. Each treatment medium was observed in five random field of view with five replications. Histologic analysis was performed aiming to observe the origin of sugarcane somatic embryo. The observation was conducted by embedding method with paraffin medium (Ruzin, 1999). The staining used was safranin (2\%). Preparation was performed under the Olympus CX22 binoculars microscope with 10x40 magnification.

\section{Results}

There was not interaction between growth regulators and medium consistency. A single factor of growth regulator significantly affected the percentage of live nodular callus whereas medium consistency had not significant effect. After 4 weeks in culture, the percentage of live callus reaches $100 \%$ in control medium or without the addition of Kinetin or BAP in both liquid and solid med-

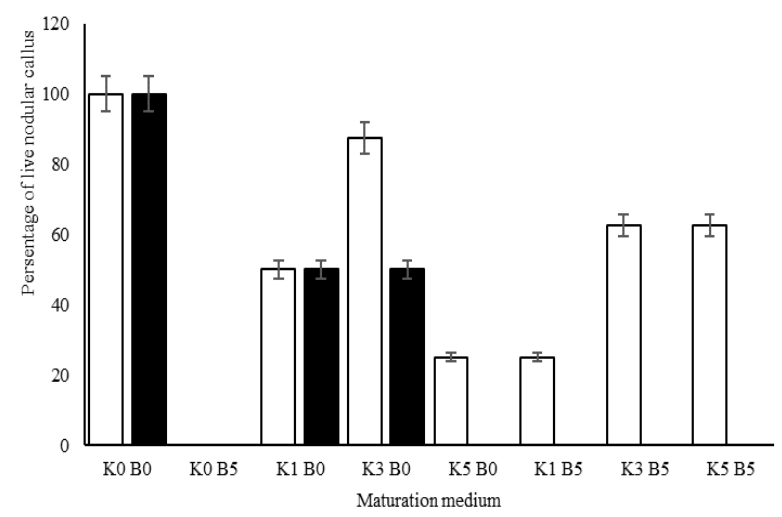

Figure 1. Percentage of live nodular callus on maturation medium of somatic embryo after 4 weeks in culture medium. The vertical line indicated Standard Error (SE) on probability $<0.01$. Solid medium ( $\square$ ), Liquid medium $(\square) \mathrm{K} 0 \mathrm{~B} 0=0 \mathrm{mg} / \mathrm{L}$ Kinetin $+0 \mathrm{mg} / \mathrm{L}$ BAP; K0B5 $=0$ $\mathrm{mg} / \mathrm{L}$ Kinetin $+5 \mathrm{mg} / \mathrm{L}$ BAP; K1B0 $=1 \mathrm{mg} / \mathrm{L}$ Kinetin $+0 \mathrm{mg} / \mathrm{L}$ BAP; $\mathrm{K} 3 \mathrm{~B} 0=3 \mathrm{mg} / \mathrm{L}$ Kinetin $+0 \mathrm{mg} / \mathrm{L}$ BAP; K5B0 $=3 \mathrm{mg} / \mathrm{L}$ Kinetin +0 $\mathrm{mg} / \mathrm{L}$ BAP; K1B5 = $1 \mathrm{mg} / \mathrm{L}$ Kinetin $+5 \mathrm{mg} / \mathrm{L}$ BAP; K3B5 $=3 \mathrm{mg} / \mathrm{L}$ Kinetin $+5 \mathrm{mg} / \mathrm{L} \mathrm{BAP} ; \mathrm{K} 5 \mathrm{~B} 5=5 \mathrm{mg} / \mathrm{L}$ Kinetin $+5 \mathrm{mg} / \mathrm{L}$ BAP 
um. Nodular callus could not be able to live in $5 \mathrm{mg} / \mathrm{L}$ BAP, but capable of living up to $60 \%$ when the medium treatment of 3 or $5 \mathrm{mg} / \mathrm{L}$ Kinetin combined with $5 \mathrm{mg} / \mathrm{L}$ BAP (Fig. 1).

Somatic embryo maturation medium did not significantly affect the number of globular embryos that were produced, but there had a significant effect on the number of embryo coleoptile. The development of somatic embryo began with the formation of globular embryo at 5 weeks after culture. In the seventh week, scutellum embryo formed. Finally, the formation of coleoptile embryo was initiated after 12 weeks in culture medium. The highest number of globular embryos (38 embryos) was produced from MS medium supplemented with 1 or $3 \mathrm{mg} / \mathrm{L}$ Kinetin combined with $5 \mathrm{mg} / \mathrm{L}$ BAP (Fig. 2). At the embryo development stage of scutellum produced 21 embryos from $3 \mathrm{mg} / \mathrm{L}$ Kinetin treatment. The MS medium contained Kinetin which combined with the BAP produced only 6 scutellum embryos. The final maturation stage was the coleoptile, the highest number (19 embryos) resulting from the addition treatment $3 \mathrm{mg} / \mathrm{L}$ Kinetin (Fig. 2). The somatic embryo formation stage that occurs indirectly preceded by the embodiment of embryogenic callus (Fig. $3)$.
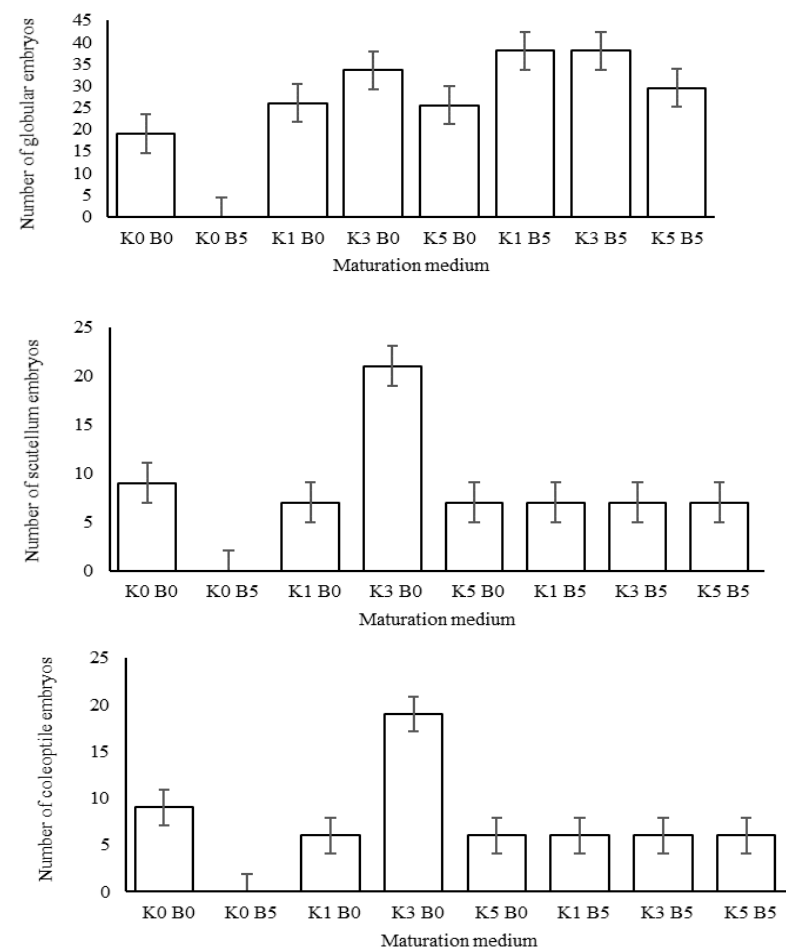

Figure 2. Number of somatic embryo in maturation medium (Kinetin and BAP). The vertical line indicated Standard Error (SE) on probability $<0.01 . \mathrm{K} 0 \mathrm{~B} 0=0 \mathrm{mg} / \mathrm{L}$ Kinetin $+0 \mathrm{mg} / \mathrm{L} \mathrm{BAP} ; \mathrm{K} 0 \mathrm{~B} 5=0 \mathrm{mg} / \mathrm{L}$ Kinetin $+5 \mathrm{mg} / \mathrm{L}$ BAP; $\mathrm{K} 1 \mathrm{~B} 0=1 \mathrm{mg} / \mathrm{L}$ Kinetin $+0 \mathrm{mg} / \mathrm{L} \mathrm{BAP} ; \mathrm{K} 3 \mathrm{~B} 0=3 \mathrm{mg} / \mathrm{L}$ Kinetin $+0 \mathrm{mg} / \mathrm{L}$ BAP; K5B0 $=3 \mathrm{mg} / \mathrm{L}$ Kinetin $+0 \mathrm{mg} / \mathrm{L}$ BAP; K1B5 $=1 \mathrm{mg} / \mathrm{L}$ Kinetin $+5 \mathrm{mg} / \mathrm{L}$ BAP; K3B5 = $3 \mathrm{mg} / \mathrm{L}$ Kinetin $+5 \mathrm{mg} / \mathrm{L}$ BAP; K5B5 = $5 \mathrm{mg} / \mathrm{L} \mathrm{Kinetin}+5 \mathrm{mg} / \mathrm{L} \mathrm{BAP}$

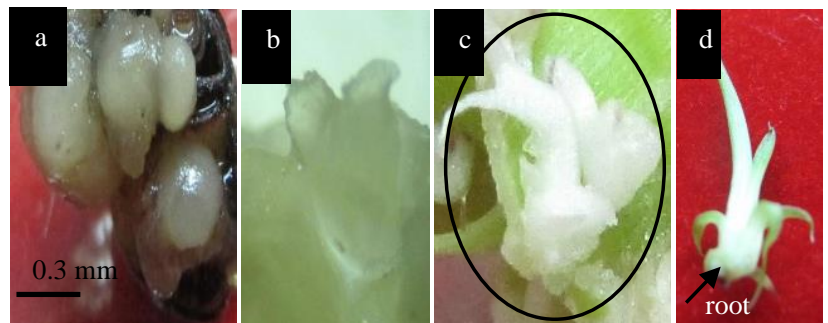

Figure 3. Formation of somatic embryo. (a) globular embryos, (b) scutellum embryo, (c) coleoptile embryo, and (d) bipolar structure

The germination medium composition has not significant effect to the percentage of bipolar embryo, root length or leaf number (Tab. 1). The MS medium with full strength supplemented with $100 \mathrm{mg} / \mathrm{L}$ glutamine was the best germination medium. This medium resulted the highest percentage of somatic embryo (73.29\%) forming bipolar structure, and the largest number of leaves $(4.58$ leaves). MS medium with half strength without addition of amino acid or growth regulator resulted number of embryo somatic germinated at least that was only $6.99 \%$. the histology observation showed that somatic embryos of sugarcane emerged from many cells through the budding process (Fig. 4). Somatic embryos in sugarcane also initiated from one cell. The stages of somatic embryo development began from cell polarization followed by asymmetric cell division (Fig. 5).

Table 1. Percentage of bipolar structure, root length, and number of leaves on germination medium

\begin{tabular}{|c|c|c|c|}
\hline $\begin{array}{l}\text { Germination } \\
\text { medium }\end{array}$ & $\begin{array}{c}\text { Percentage of } \\
\text { bipolar structure } \\
(\%)\end{array}$ & $\begin{array}{c}\text { Root } \\
\text { length } \\
(\mathbf{c m})\end{array}$ & $\begin{array}{l}\text { Number } \\
\text { of leaves }\end{array}$ \\
\hline $\begin{array}{c}1 / 2 \mathrm{MS}+20 \mathrm{~g} / \mathrm{L} \\
\text { sukrosa }\end{array}$ & 6.99 & 1.18 & 1.67 \\
\hline $\begin{array}{l}\mathrm{MS}+20 \mathrm{~g} / \mathrm{L} \\
\text { sukrosa }\end{array}$ & 36.63 & 2.81 & 4.03 \\
\hline $\begin{array}{l}1 / 2 \mathrm{MS}+20 \mathrm{~g} / \mathrm{L} \\
\text { sukrosa }+ \text { Glu }\end{array}$ & 39.96 & 2.81 & 1.82 \\
\hline $\begin{array}{c}\mathrm{MS}+20 \mathrm{~g} / \mathrm{L} \text { sukrosa } \\
+\mathrm{Glu}\end{array}$ & 73.29 & 1.87 & 4.58 \\
\hline $\begin{array}{c}1 / 2 \mathrm{MS}+20 \mathrm{~g} / \mathrm{L} \\
\text { sukrosa }+\mathrm{Glu}+\mathrm{BAP} \\
+\mathrm{BA}\end{array}$ & 13.32 & 0.69 & 1.68 \\
\hline $\begin{array}{c}\mathrm{MS}+20 \mathrm{~g} / \mathrm{L} \text { sukrosa } \\
+\mathrm{Glu}+\mathrm{BAP}+\mathrm{BA}\end{array}$ & 36.63 & 1.73 & 1.76 \\
\hline
\end{tabular}

Glu $=100 \mathrm{mg} / \mathrm{L}$ glutamine; BAP $=0.3 \mathrm{mg} / \mathrm{L} ; \mathrm{IBA}=0.5 \mathrm{mg} / \mathrm{L}$

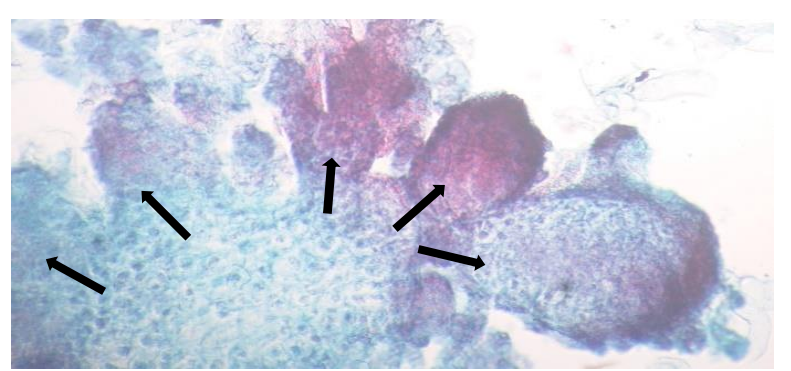

Figure 4. Primary somatic embryo form budding. The formation of proembryo after 5 weeks in culture shows a budding phenomenon that developed from the basal region of the callus (shown by arrows) 


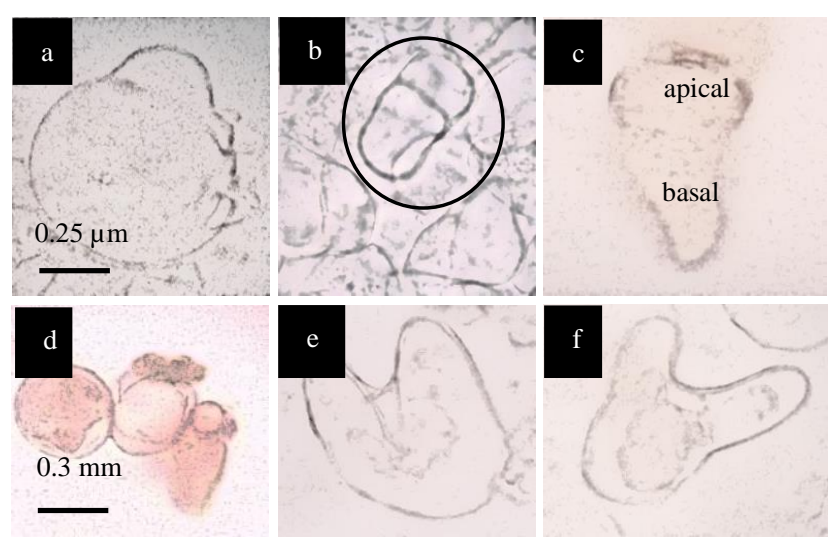

Figure 5. Stages of somatic embryogenesis of sugarcane. (a) cell polarization, (b) asymmetric division, (c) two cells consisting of apical cells and basal from transversal division (d) globular embryo, (e) scutellum embryo, and (f) coleoptile embryo

\section{Discussion}

\section{Maturation of Somatic Embryo}

The formation of somatic embryo in sugarcane began from the multiplication of embryogenic cells found on the edge of the callus. That was demonstrated by the cells: clear nuclei, solid cytoplasm, strong color absorption, and high regeneration. After forming the nodular callus and then directly follow by the maturation of somatic embryo induction. This stage was important to be conducted, so the nodular callus was able to form somatic embryo. Percentage of live nodular callus reached $100 \%$ at 4 weeks after culture in control medium or without addition of Kinetin or BAP either in liquid or solid medium. The callus nodular could not survive at $5 \mathrm{mg} / \mathrm{L} \mathrm{BAP}$, otherwise when medium combined with 3 and $5 \mathrm{mg} / \mathrm{L}$ Kinetin that was resulted percentage of live callus reached 60\% (Fig. $1)$.

The maturation medium of somatic embryo had significant effect to the number of globular somatic embryo, scutellum, and coleoptile. The highest number of globular embryos produced on the maturation medium was 38 embryos from the medium treatment with the combination of Kinetin and BAP, whereas the absence the addition of a growing regulator only produces 19 embryos (Fig. 2). The highest number of scutellum embryos was produced from $3 \mathrm{mg} / \mathrm{L}$ Kinetin (21 embryos), whereas when combined with Kinetin and BAP the number of scutellum embryos produced was low (6 embryos). The final maturation stage was the coleoptile, the highest number resulted from the addition of $3 \mathrm{mg} / \mathrm{L}$ Kinetin was 19 embryos. The addition of Kinetin in the medium proved the capablity of inducing somatic embryo formation with MS medium. Kinetin is an amino purine or derivative of an adenine cytokine. The combination of cytokinin play an important role in encouraging the development of somatic embryos. Cytokinin play a role in cell division and nodular callus proliferation. The addition of exogenous growth regulators has been shown to be necessary for somatic cell activation and cell division. In general, cytokines are essential during the initiation phase of cell division from somatic embryos (Karami et al., 2009).
The formation of somatic embryos that occur indirectly through the nodular callus began with the formation of globular embryos (Fig. 3) after 5 weeks in the culture medium. This somatic embryo was formed from cells with thick cytoplasm. According to Toonen \& de Vries (1996), in monocot plants, globular embryos developed into embryos that had suspensors. Then the globular embryo developed to form scutellum embryo which characteristic of the monocot embryo followed by differentiation to form coleoptile namely shoot and root primordia. This was in accordance with Utami et al. (2007a, b) research on Phalaenopsis amabilis plants that scutellum was formed on the lateral portion of the embryo, root primordia and shoots develop at the ends of the embryonic axis. Scutellum embryo then developed into a single cotyledon. Further development of morphologically somatic embryos from the globular stage and similar to the development of zygotic embryos. The somatic embryos produced from this study were primary somatic embryos derived from embryogenic callus atthe first induced.

\section{Germination of Somatic Embryo}

The germination medium did not give significant effect to the percentage of bipolar embryo, root length or number of leaf. The MS medium with full strength that was added $20 \mathrm{~g} / \mathrm{L}$ sucrose and $100 \mathrm{mg} / \mathrm{L}$ glutamine resulted the highest percentage of bipolar structure $(73.29 \%)$, as well as the number of leaves (4.58) (Table $1)$. The half strength of MS medium and glutamine as germination medium proved to inhibit the formation of bipolar structures which resulted low number for length of roots and number of leaves. The germination stage was the stage of somatic embryo to form a bipolar structure that would develop shoots and roots. In germination medium, the cytokinin growth regulator concentrations used were very low or without growth regulators. According to Mariska et al. (2001), GA3 was often added to induce germination stage. Germination stage was the most difficult stage. Many studies of sugarcane somatic embryos did not succeed in obtaining the germination stage. Generally, shoot and root induction was done by adding a growth regulator to produce the planlet.

\section{Histology and Microscopic Observation}

The multicellular of somatic embryos have been occur through the meristematic budding event (Fig. 4) from observation of histological. Somatic embryos could be formed from single cells but also could be formed from multicellular budding (Gahan \& George, 2008). The results of this study were similar to those obtained by Alcantara et al. (2014) on sugarcane cultivars RB85516 and RB72454 where somatic embryos were formed from phenomena of multicellular through budding process. Stages of somatic embryo development of sugarcane began from cell polarization followed by asymmetric cell division (Figs. 5a, b). Asymmetrical division would produce two unequally sized cells that develop into apical cells (small cell size) and basal (large cell size) resulting from transverse division of the long embryo axis (Fig. $5 \mathrm{c}$ ), then divided into 4 quadrant cells. Then formed globular embryo (Fig. 5d). Then there was a bulge that 
developed into scutellum embryo (Fig. 5e). Alcantara et al. (2014) found a pro-embryo on the Saccharum structure similar to the pro-embryo in the zygotic embryo and then the bulge was developed as scutellum. The final stage of embryo somatic was coleoptile (Fig. 5f). This stage was the most risk stage because many studies of somatic embryogenesis had failed in the formation of coleoptile embryos. The coleoptile form showed one cotyledon which distinguishes between monocot and dicot. The dicots plant has two cotyledons that develop from the heart phase to the torpedo form.

Histological analysis showed that somatic embryos of sugarcane emerged from many cells through the budding process. Somatic embryos in sugarcane could also form from one cell. The development of somatic embryo began

\section{Acknowlegment}

This research was supported by the Ministry of Research and Technology Ministry of Higher Education with the number of contracts: 797/K3/SPK.LT/2016 dated June 14, 2016. Thanks also to ICABIOGRAD and ICECRD for all research facilities support. Thanks also to Dr. Utut Widyastuti (deceased) for guidance during the research.

\section{References}

Alcantara, G. B., Dibax, R., Oliveira, R. A., Carlos, J., Filho, B., \& Daros, E. (2014). Plant regeneration and histological study of the somatic embryogenesis of sugarcane (Saccharum spp.) cultivars RB855156 and RB72454. Maringá, 36(1), 63-72.

Chengalrayan., Abouzid, K., \& Meagher, A. G. (2005). In vitro regeneration of plants from sugarcane seed-derived callus. In Vitro Cellular \& Developmental Biology, 41(4), 477-482.

Desai, N. S., Suprassana, P., \& Bapat, V. A. (2004). Simple and reproducible protocol for direct somatic embryogenesis from cultured immature inflorescence segments of sugarcane (Saccharum spp.). Current Science, 87(6), 764-768.

Gahan, P. B., \& George, E. F. (2008). Adventitious Regeneration. In Edwin FG, Michael AH, Geert-Jan De K (eds). Plant Propagation by Tissue Culture (pp.355). Netherland: Springer.

Gandonou, C. H., Errabi, T., Abrini, J., Idaomar, M., Chibi, F., \& Senhaji, N. S. (2005). Effect of genotype on callus induction and plant regeneration from leaf explants of sugarcane. African Journal of Biotechnology, 4(11), 1250-12s55.

Gill, N. K., Gill, R., \& Gosal, S. S. (2004). Factors enhancing somatic embryogenesis and plant regeneration in sugarcane (Saccharum officinarum L.). Indian Journal of Biotechnology, 3, 119-123.

Haq, I. U., \& Memon, S. (2012). Efficient plant regeneration through somatic embryogenesis in sugarcane (Saccharum officinarum with the formation of globular embryos after 5 weeks in culture medium. In the seventh week, there was formation of scutellum embryo and finally the formation of coleoptile embryo after 12 weeks in culture medium.

This study included the study of somatic embryogenesis of sugarcane PS 864 where one of the early stages through in vitro breeding was the provision of a method for the process of somatic embryogenesis. Protocol of induction techniques of somatic embryogenesis and its regeneration is essential for use in genetic transformation activities. Through somatic embryo regeneration can be generated high transformation efficiency value and avoid the occurrence of chimera.

L.) cultivar CPF-237. African Journal of Biotechnology, 11(15), 3704-3708

Karami, O., Aghavaisi, B., \& Pour, A. M. (2009). Molecular aspect of somatic embryogenic transition in plant. Journal Chemistry Biology, 2, 177-190.

Mariska, I., Hutami, S., Kosmiatin, M., Husni, A., Adil, W., \& Supriati, Y. (2001). Somatic embryogenesis in different soybean varieties. Proc. Workshop on Soybean Biotechnology Al Tolerance on Acid Soils and Disease Resistance. Biotechnology Indonesia-Germany Project. Directorate for Assessment and Technology, Agency for the Assessment and Application of Technology Federal Ministry for Education and Research, Central Research Institute for Food Crops. 14-15 Sept. 1999. Bogor.

Murashige, T., \& Skoog, F. (1962). A revised medium for rapid growth and bioassay with tobacco tissue culture. Physiol Plant, 15, 473-497.

Naz, S., Ali, A., \& Siddique, A. (2008). Somatic embryogenesis and plantlet formation in different varieties of sugarcane (Saccharum officinarum L.) HSF-243 and HSF-245. Sarhad Journal of Agriculture, 24(4), 593-598.

Pennycooke, J. C., \& Towill, L. E. (2011). Medium alterations improve regrowth of sweet potato (Ipomea batatas (1.) lam.) shoot tips cryopreserved by vitrification and encapsulation-dehydration. CryoLetters, 22, 381-389.

Ruzin, S. E. (1999). Plant Microtechnique and Microscopy. New York, NY: Oxford University.

Taylor, M. G., \& Vasil, I. K. (1996). The ultrastructure of somatic embryo development in Pearl Millet (Pennisetum glaucum; Poaceae). American Journal of Botany, 83(1), 28-44.

Toonen, M. A. J., \& de Vries, S. C. (1996). Initiation of somatic embryos from single cells. In: Wang TL, Cuming A (eds). Embryogenesis the generation of plant. Oxford: Bios Scientific.

Utami, E. S. W., Sumardi, I., Taryono., \& Semiarti, E. (2007a). Pengaruh $\alpha$-Naphtaleneacetic Acid (NAA) terhadap embriogenesis somatik anggrek bulan Phalaenopsis amabilis $\mathrm{L}$. Jurnal Biodiversitas, 8(4), 295-299.

Utami, E. S. W., Soemardi, I., Taryon., \& Semiarti, E. (2007b) Embriogenesis somatik anggrek bulan Phalaenopsis amabilis (1.) BI: struktur dan pola perkembangan. Berk. Penel. Hayati, 13, 33-38. 